\title{
Revisiting the Relevance of School Closure Policy as Efforts to Prevent COVID-19 Infection among Students in Indonesia
}

\author{
Arnadi \\ Institut Agama Islam Sultan Muhammad Syaifuddin Sambas, Indonesia
}

Corresponding Author: Arnadi, @ drarnadi2016@gmail.com

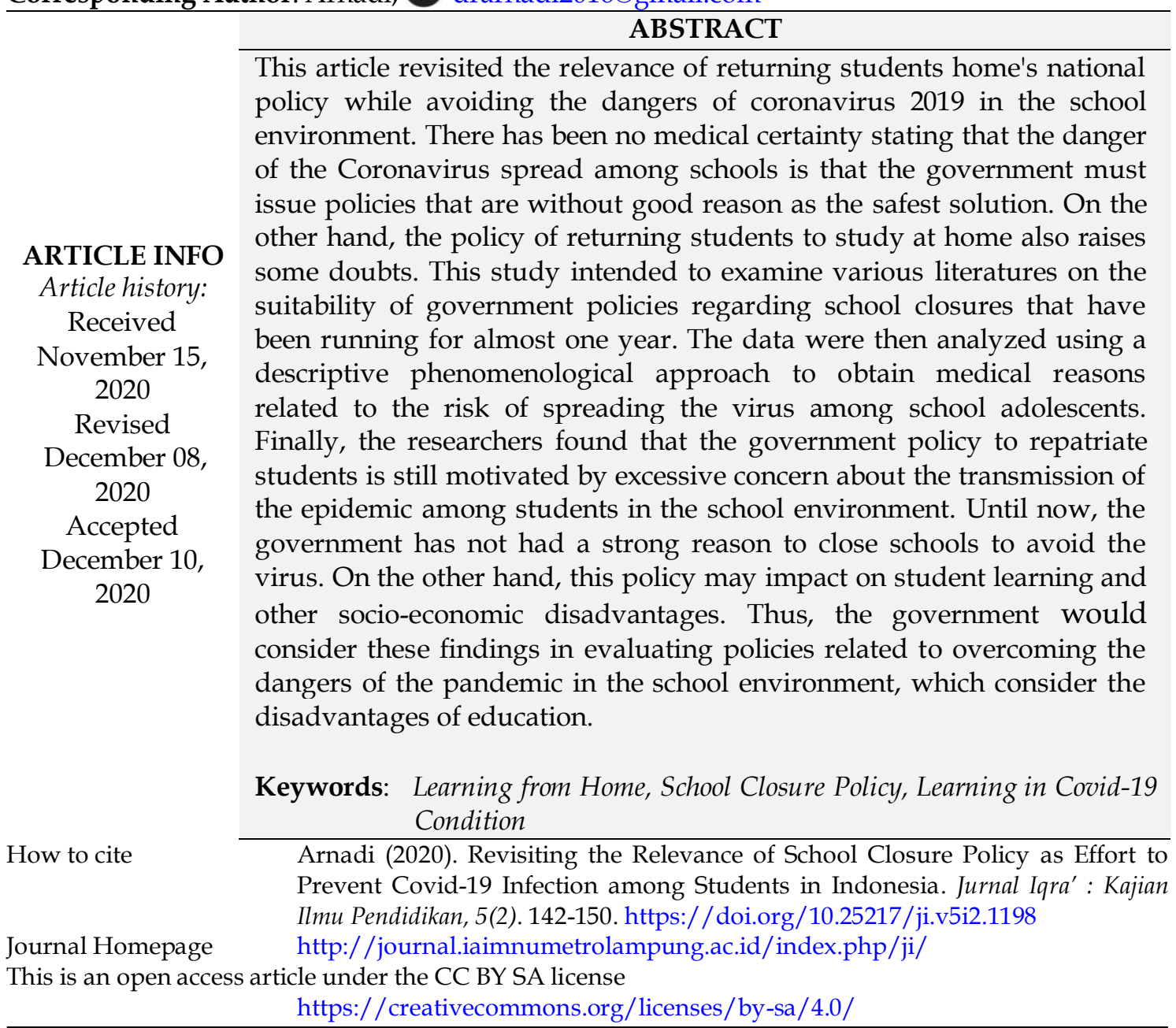

\section{INTRODUCTION}

The government response to the spreading of the coronavirus 2019 (COVID-19) pandemic has caused some countries to close business activities, including the school in Indonesia (Setiawan, 2020; Putra et al., 2020). Simultaneous and sudden school closings are a solution to avoid the spread of the deadly virus among students in the school environment. However, in several countries that have implemented the pandemic emergency response plan, schools are not closed suddenly and simultaneously. The solution is based on the belief that there was no medical evidence that said the percentage of the potential spread of COVID-19 among students was very significant compared to adults. The findings of Hale et al., (2020), Islam et al., (2020), Fetzer et al., (2020) regarding various government responses in responding to the spread of the virus among the education community are varied. The government's 
work experience regarding school safety from the dangers of infectious varies from country to country in some countries. Whereas the policy practices are not as good as developed countries, the decision to close schools has not been based on studies and medical and educational experts' considerations. In other words, the policy of closing schools and being replaced by distance learning is not based on joined decisions and advice from experts who understand the dangers of the spread of a pandemic and the risk of learning disadvantages for the sudden government policy.

Revisiting a study on the national policy of sending students learning remotely from home during a pandemic is a significant undertaking requiring all parties' attention. When the policy comes in a sudden, there is an element of weakness and even error. The above study is needed to review the policy by analyzing and comparing thousands of other studies in other countries that have globally experienced the same disruption as the national response. However, of course, different countries have practiced different strategies and solutions (Fauzi, \& Khusuma, 2020; Ichsan, 2020). Efforts to review this policy, the researchers believe, would help the government and the school community implement policies during the evaluation of the effectiveness of this policy. What Sahu, (2020) is worried about closing universities due to COVID-19 because it has an impact on the educational area and mental health of students, and staff needs in-depth analysis study. The result is increased government effectiveness in setting rules and procedures and creating quality policies for quality learning services, protection, security, expectations, and accountability. Through this study, state school operations would have a correct understanding of why they dare to reopen or keep closing them. In other words, schools also have the strength, structure, and function needed to meet the standards of national education practice, namely students continue to learn while protecting themselves from the threat of COVID-19 infection.

If looking at the trend of closing schools in response to the virus, the data shows differences in how each country responds. For example, what applies in Sweden seems safe enough that they keep opening schools. The Swedish health service reported on July 15 that the COVID-19 outbreak among 1 million schoolchildren was not as bad as the condition of schoolchildren in neighboring Finland, which indeed closed schools from the onset of the outbreak. Pediatricians have seen some severe cases of infection among school-age children in Stockholm. However, only one Swedish child believed to have died from the Coronavirus since the outbreak began. In response, officials in Stockholm have admitted they do not know how the disease affects teachers, parents $\mathrm{d}$ other adults in schools. Furthermore, Sweden had more than 70,000 cases of the pandemic as of July 21, placing it at the center of the group in Europe, according to a joint study from Sweden's Upsala University and the University of Virginia. Of these, a little over 1,000 involved children and adolescents. Spires, (2020) stated that many other leaders have reopened their schools during the pandemic and what the others can learn from those reopening. It must be admitted that the effort to evaluate each government policy precisely and thoroughly regarding the stability of the decision to close schools to reduce the risk of contracting the pandemic among school students is challenging even in developed countries. It is because making demanding decisions is very out of balance with the sudden arrival of COVID-19. It is also proven by Cauchemez et al., (2008) who estimate the effectiveness of the policy of closing schools in several countries to avoid influenza transmission does not correlate. According to them, the decision that could be categorized as school closure had little correlation with the pandemic spread. Prove their study; a medical calculation model study was 
used to evaluate the impact of school closures. If qualitative data were available, the model study data would reinforce the rebuttal to transmit the pandemic in the school environment. On that basis, the researcher would like to review some of the data in the qualitative form to integrate it with all mathematical, medical studies.

\section{METHOD}

This review's main objective was to revisit the relevance of school closure policies to prevent COVID-19 transmission among students. To revise the government's policy on the continuity of education after the COVID-19 pandemic hit Indonesia, which has now been in for almost a year, the researcher would like to review this policy again by presenting the findings of studies and updating information on how several countries have responded to virus transmission in their school environment, especially what the modeling study said on school-aged children COVID-19 infectious. To achieve this study's objectives, researcher had done preliminary reading by citing many related articles to obtain information and data directly related to the topic of discussion. After understanding the introduction, then present a general comparison of how the researcher reviewed government policies towards school closures and the impact on both outputs and difficulties for families and teachers in supporting students learning remote methods. Then the researcher summarize our findings, which include; Next, the researcher review the findings and ensure that elements of validity and reliability. the researcher believe our study method is correct, as directed by Flick, (2013), in which he has turned his book into a guidebook for the study of qualitative analysis of SAGE, an industry activity for journals and other publications.

\section{RESULT AND DISCUSSION}

\section{Age as a potential factor}

Medically, everyone of all ages has the potential to contract COVID-19. Although many think that young and older people alike can be infected with this virus, it seems that older adults and individuals of all ages who are medically ill or who have or are suffering from previous illnesses such as asthma, hypertension, diabetes, and heart disease seem to be the sooner catch it. In other words, they are more likely it is to see COVID-19 and become seriously ill during this pandemic, and this can lead to fatalities. Our findings suggest that patients aged 17 years and under are less likely to catch COVID-19 than patients over 20 years of age. The percentage of those who suffer from congenital diseases other than coronavirus infection is greater than that of healthy and healthy adolescents. Like many modeling studies, the results show that the researcher can change government policy analysis during a pandemic. Likewise, the school population measured in several surveys to prove school crowds may not be the same as the pattern of contact made by the elderly in the middle of the 2020 period when COVID-19 first entered Indonesia.

\section{Closed room}

The impact of transmission of the virus increases in confined spaces where ventilation is poor is significant. Viruses also like cooler temperatures than air conditioning. Health and respiration scientists have discovered an excellent potential for airborne or airborne transmission of the Coronavirus. Airborne transmission risk increase folds, especially in air-conditioned closed space, such as meeting rooms, restaurants, and city buses. Several factors affect the increased risk of airborne transmission of the virus that causes Covid-19. For example, the air circulation, which 
is mentioned above, is a bigger chance of being infected with Covid-19 is higher in closed spaces than in the wild.

Our study seeks to take data from a qualitative approach to evaluate the suitability of government policies to send students and teachers back to virtual learning from home on the grounds of avoiding the spread of the virus among schools in Indonesia. the researcher assume that closing schools' policy on stopping the transmission of COVID-19 is not based on the adequacy of preparing evidence of scientific studies by related experts such as medics and the findings of studies from teaching experts. The researcher believe what applies to this decision-making is the government's inability to link the significance of school closings to halting the spread of the Coronavirus. We can also question how effective this policy has stopped transmission and how much has lost education since this policy was implemented. Not to mention the economic impact of economic loss since this policy was implemented, where more and more parents have to stay home to look after their children and not work.

\section{Risk Activities}

More people have returned to their daily activities after entering the new expected time. However, the most crucial factor in avoiding the occurrence of transmission of the Coronavirus during this pandemic is students to be familiar with daily activities in school with each risk of transmission. Students are tired of working from home. However, the outbreaks are not over, and it is essential to recognize that infectious COVID-19 in Indonesia. When more public places such as restaurants, salons, and school reopen, it is good to remember that some activities are still much more at risk of transmitting the Coronavirus from one person to another. Good hand washing habits, especially before eating or touching the face, keeping a distance from other people, and wearing masks in public, are protocols that must be maintained. So that students can protect themselves from the transmission of the Coronavirus, because it is known that several daily activities have the risk of transmission from lowest to highest.

\section{Children at risk}

Children who are susceptible to contracting COVID-19 areas our study's findings prove that the group of children most vulnerable to the danger of being infected with the Coronavirus is children of refugees or migrants. Meanwhile, the indigenous groups are from the group of street children who are internally displaced, children deprived of freedom, children living wild without care, groups of children living on the streets and urban slum areas, people with disabilities, and children living in affected conflict areas. These groups are usually vulnerable to the transmission of COVID-19, which must be given special attention and protection together.

\section{The infectious in schools}

Our series of reviews have not found severe transmission between students and students to the teacher council. In April 2020, several scientists at the Pasteur Institute, received support from the French government, especially the education implementing authority, conducted an epidemiological survey study on thousands of students attending elementary schools in Crépy-en-Valois. Their research also received support from the collaboration of the Crépy-en-Valois community. A survey study using a serological test developed by the Pasteur Institute revealed that the percentage of elementary school students who contracted the 2019 coronavirus was $8.0 \%$. Based on several cases of transmission detected in students before the school was closed, it 
appears that spreading did not occur to students or teachers or other staff at the school. The results were published online in Pasteur on July 23, 2020.

Munro and Faust, (2020) have indicated that children are not super-spreaders of COVID-19 when they come home. They proved that it was very wrong to see schools as centers of transmission of the virus. Seeing how virus cases have been circulating outside the school environment since early 2020, the number of cases has gradually increased until early March before stabilizing and then starting to fall in late March. Of the 1,340 people studied, only 139 had infected, or $10.4 \%$ of the people studied as a comparison of 510 students from six primary schools studied, three possible COVID-19 infection cases in three different schools before regular holiday school. These cases do not lead to secondary cases among school students or teaching staff. Teachers were only slightly affected, with only $7.1 \%$ of teachers infected, a figure similar to the number of parents of uninfected children in the study who infected with the virus $(6.9 \%)$. For non-teaching staff, the proportion of infections (3.6\%). So the infection rate was very high in parents of infected children $(61.0 \%)$, but only $6.9 \%$ in parents of uninfected children. It suggests that parents are the source of transmission to their children in some cases (Sheikh et al., 2020; Stein-Zamir et al., 2020; Todo, n.d.).

\section{The importance of revisiting}

This paper aims to revisit government policy that has sent students home to study remotely in response to the dangers of COVID-19 in Indonesia that has impacted many business activities in human life, especially learning activities at school to stop. All parties agree on every national policy, but on the other hand, all parties also feel disadvantaged if the decision to close schools is not permanent. So on that, the researcher conducted this research with the hope of providing new enlightenment to catch up with student learning outcomes that had been neglected for almost a year while still protecting students from the threat of a deadly virus.

Acknowledging what Viner et al., (2020) found have proved that school closures and policy management practices during the coronavirus outbreak in each country require systematic review and are urgent to consider. Their revisiting doubts that children and adolescents' health is closely related to the spread of the virus among schools. Looking at infection data in China, which is the country of origin of the 2019 coronavirus, this new strain reported having killed more older adults with a history of other diseases. The COVID-19 has confirmed to have attacked all walks of life and more to people's travel history previously contacted. For more details on the aspects most vulnerable to COVID-19 in Indonesia, researches data collected around April 2020. Our review found that 87 percent of patients from 72,314 cases in China in midFebruary were in the 30-79-year-old group. Other data shows that only 8.1 percent of patients are 20 years old, 1.2 percent are teenagers, and 0.9 percent are under ten years old.

Furthermore, the $\mathrm{WHO}$ released 78 percent of China patients in the same period suffered by patients aged 30-69 years. The Chinese government found that 2.3 percent of the confirmed cases were fatal or the patients died. The mortality rate was up to 14 percent among patients over 80 years of age. The mortality rate drops to just 1.3 percent for patients in their 50s, 0.4 percent for patients in their $40 \mathrm{~s}$, and 0.2 percent for 10-39 years.

\section{Positive implication}

Azevedo et al., (2020) have simulated the potential impact of COVID-19 by closing schools and their relation to learning outcomes. Linking the government's policy of repatriating students to study remotely in response to the 2019 coronavirus 
pandemic has made us aware that such policies need to be reviewed first, when the government and hundreds of other countries simultaneously close schools throughout the region, in particular. the red zone, until October 2020, while several other countries have reopened their schools. The researcher reviewed this policy because almost no one knows that policy precisely whether the decision to close schools has been an effective solution in fighting the coronavirus outbreak among school students. Meanwhile, many studies have proven that losing a year of learning can harm students for years. We are conducting a review of the government's policy of closing schools and opening classrooms online. There are severe problems both from virtual learning readiness.

We review the government's policy of closing schools in response to the dangers of the Coronavirus in the school environment is part of the concern of educators and observers of education sustainability issues (Siryeh, 2020). The closing schools' policy but opening online classrooms have raised many severe problems, including that virtual learning readiness is an unusual way of learning for most of the education community in developing countries, so it has created more uncertainty about Indonesia's future education young generation. From many e-literature reviews, the researcher identified and understood the effectiveness of student learning and closed schools and replaced them with distance learning systems during the Coronavirus outbreak has impressed students, especially those who are geographically and geographically disadvantaged (Surani, \& Hamidah, 2020).

\section{Impact on future education}

All have to be aware of how government policy in the past will impact future Indonesian generation. The closure of schools was carried out quickly in all provinces at the beginning of the lockdown period and then followed by schools' closure in big cities marked by a regional zone system such as the red and green zone, which was not the right choice. There is no actual data on a significant relationship between school closure and control of case-by-case transmission in the school environment (Ilyasa et al., 2020). Data on the outbreak in China as the first region of this outbreak confirms that school closures do not correlate with infection control, especially school environments with a population of teenagers. Various modeling studies in many countries prove results that do not support this government policy.

For example, Kucharski et al., (2020) state that the initial dynamics of virus transmission and control in schools and the general public is quantitative. The COVID19 is a highly contagious disease, but a recent study modeling study predicts that closing schools would prevent $2-4 \%$ of the virus's spread, which is much less than other social distancing intervention policies. In other words, there is a more significant loss in the quality of education with infection, which, on average, can heal itself by adolescent patients.

When an individual government policy made in the past was not right, today's citizen has the right to revisit and correct it. So, the spread of cases widely reported has proven that the age factor is most vulnerable to exposure, namely a low percentage of patients in school-age adolescents. It could be because younger people are less susceptible to pandemic and less exposed to clinical symptoms after infection. Therefore the transmission method can be very compatible with the various available data about the distribution method of the cases found. For studies looking for modes of infection among close contacts such as crowds, age-specific susceptibility to COVID-19 infection, and specific age older between 40 and over were reported. 
Our review results mean that the effectiveness of the policy of returning students home to reduce the transmission of COVID-19 is likely to be inappropriate compared to the way of contracting it at other places of death. The implications of our review's findings would be taken into consideration in making decisions that are expected, especially in green zones. For Indonesia, which has a young population that needs to be active in school, it may be necessary to consider the school closure policy for too long because there would be a decline and laying loss and the severity of the projected economic burden of its citizens.

Based on the findings and discussion above, the researcher can summarize this discussion into a review of the government's policy to close schools and open classes remotely to respond to the corona outbreak, which has left students behind in learning for almost a year. This study is very reasonable considering the same number of countries closed schools due to the COVID-19 response; on average, they have reopened all of their schools, or some are still optional. As researchers, we can review all previous information and studies related to our topic, hoping that policymaking would get input, which means that every time they plan, new policymakers would continue to close schools for the pandemic response or reopening soon. As a supporter and comparison, the government can undoubtedly refer to each policy on the same study and applied in the Indonesian context.

\section{CONCLUSION}

Looking at the findings above on a review of government policies on school closures during COVID-19 with evidence of previous studies, transmission of the Coronavirus generally occurs in the elderly. History of congenital diseases is a factor in causing people exposed to fatal consequences. No matter how intensive the treatment is. In other words, age is a potential factor in being exposed to a pandemic. From case to case, the most potential for virus transmission is the message's location or place. It means that government protocol is imperative that we must heed it together. For example, students can still go to school but must follow the directions and guidelines for COVID, such as washing hands and social distancing. Avoid confined spaces and self-isolation to slow the spread. Transmission can also occur as an occupational risk. It means that no one can be sure which method is the most effective. Even so, efforts remain very necessary, such as avoiding confusion. Schools can still go to school as long as they can regulate with the safest safety standards for COVID-19 protection. The risk of infection among children is shallow compared to the average transmission among adults. It means leaving the child out of school, but the children roam freely in an uncontrolled environment. Transmission from schools has no valid data such as transmission in free environments such as markets, buildings, and tourist attractions.

\section{ACKNOWLEDGEMENT}

Thank you for the team from LP2M that helped me to finish this research.

\section{AUTHOR CONTRIBUTION STATEMENT}

The author had fully taken participation in the research conduction and fully approved the final product of the manuscript writing.

\section{REFERENCE}

Azevedo, De, J.P.W., Hasan, Amer, Goldemberg, Diana, Iqbal, Aroob, S., Geven, Martijn, K., 2020. Simulating the Potential Impacts of COVID-19 School 
Closures on Schooling and Learning Outcomes : A Set of Global Estimates (English). World Bank 1. Google Sholar

Cauchemez, S., Valleron, A. J., Boelle, P. Y., Flahault, A., \& Ferguson, N. M. (2008). Estimating the impact of school closure on influenza transmission from Sentinel data. Nature, 452(7188), 750-754. https:// doi.org/10.1038/nature06732

Fauzi, I., \& Khusuma, I. H. S. (2020). Teachers' elementary school in online learning of COVID-19 pandemic conditions. Jurnal Iqra': Kajian Ilmu Pendidikan, 5(1), 58-70. https://doi.org/10.25217/ji.v5i1.914

Fetzer, T., Witte, M., Hensel, L., Jachimowicz, J., Haushofer, J., Ivchenko, A., Caria, S., Reutskaja, E., Roth, C., Fiorin, S., 2020. Global behaviors and perceptions in the COVID-19 pandemic. Google Scholar

Flick, U. (Ed.). (2013). The SAGE handbook of qualitative data analysis. Sage. Google Scholar

Hale, T., Petherick, A., Phillips, T., Webster, S., 2020. Variation in government responses to COVID-19. Blavatnik Sch. Gov. Work. Pap. 31. Google Scholar

Ichsan, I. Z., Rahmayanti, H., Purwanto, A., Sigit, D. V., \& Rahman, M. M. (2020). PEBCOVID-19: Analysis of Students Behavior and ILMIZI Model in Environmental Learning. Jurnal Iqra': Kajian Imu Pendidikan,5(1), 1-11. https://doi.org/10.25217/ji.v5i1.901

Islam, N., Sharp, S.J., Chowell, G., Shabnam, S., Kawachi, I., Lacey, B., Massaro, J.M., D'Agostino, R.B., White, M., 2020. Physical distancing interventions and incidence of coronavirus disease 2019: natural experiment in 149 countries. bmj 370.

Ilyasa, F., Rahmayanti, H., Muzani, M., Ichsan, I. Z., \& Suhono, S. (2020). Environmental Education for Prevent Disaster: A Survey of Students Knowledge in Beginning New Normal of COVID-19. International Journal on Advanced Science, Education, and Religion, 3(2), 1-8. https://doi.org/10.33648/ijoaser.v3i2.60

Kucharski, A. J., Russell, T. W., Diamond, C., Liu, Y., Edmunds, J., Funk, S., ... \& Davies, N. (2020). Early dynamics of transmission and control of COVID-19: a mathematical modelling study. The lancet infectious diseases. https://doi.org/10.1016/S1473-3099(20)30144-4

Munro, A. P., \& Faust, S. N. (2020). Children are not COVID-19 super spreaders: time to go back to school. Archives of disease in childhood. https://doi.org/10.1136/archdischild-2020-319866

Putra, P., Liriwati, F. Y., Tahrim, T., Syafrudin, S., \& Aslan, A. (2020). The students learning from home experiences during Covid-19 school closures policy in Indonesia. Jurnal Iqra': Kajian Ilmu Pendidikan, 5(2), $30-42$. https://doi.org/10.25217/ji.v5i2.1019

Sahu, P. (2020). Closure of universities due to Coronavirus Disease 2019 (COVID-19): impact on education and mental health of students and academic staff. Cureus, 12(4). https:/ / dx.doi.org/10.7759\%2Fcureus.7541

Setiawan, A.R., 2020. Scientific Literacy Worksheets for Distance Learning in the Topic of Coronavirus 2019 (COVID-19). Google Scholar

Sheikh, A., Sheikh, A., Sheikh, Z., \& Dhami, S. (2020). Reopening schools after the COVID-19 lockdown. Journal of global health, 10(1). https://dx.doi.org/10.7189\%2Fjogh.10.010376 
Siryeh, A.D., 2020. Establishing effective school policy on discipline and attendance in secondary schools in Liberia (PhD Thesis). Notre Dame University-Louaize. Google Scholar

Spires, R.W., 2020. How Other Countries Reopened Schools during the Pandemic-And What the US can Learn from Them. The Conversation. Google Scholar

Stein-Zamir, C., Abramson, N., Shoob, H., Libal, E., Bitan, M., Cardash, T., ... \& Miskin, I. (2020). A large COVID-19 outbreak in a high school 10 days after schools' reopening, Israel, May 2020. Eurosurveillance, 25(29), 2001352. Google Scholar

Surani, D., \& Hamidah, H. (2020). Students Perceptions in Online Class Learning During the Covid-19 Pandemic. International Journal on Advanced Science, Education, and Religion, 3(3), 83-95. https:// doi.org/10.33648/ijoaser.v3i3.78

Todo, V., n.d. Medidas para que los administradores de escuelas de kínder a 12. o grado se preparen para reabrir de manera segura en el otoño del 2020 Medidas para que los administradores de escuelas de kínder a 12. o grado se preparen para reabrir de manera segura en el otoño del 2020. Google Scholar

Viner, R.M., Russell, S.J., Croker, H., Packer, J., Ward, J., Stansfield, C., Mytton, O., Bonell, C., Booy, R., 2020. School closure and management practices during coronavirus outbreaks including COVID-19: a rapid systematic review. Lancet Child Adolesc. Health 4, 397-404. https://doi.org/10.1016/S23524642(20)30095-X

Copyright Holder :

(C) Arnadi, A. (2020).

First Publication Right :

(C) Jurnal Iqra' : Kajian Ilmu Pendidikan

This article is under:

(ㅇ)(1) (2) 